\title{
Purinergic regulation of brain catecholamine neurotransmission: In vivo electrophysiology and microdialysis study in rats
}

\author{
Eliyahu Dremencov ${ }^{1,2}$, Lubica Lacinova ${ }^{1,3}$, Gunnar Flik ${ }^{4}$, Joost H. A. Folgering ${ }^{4}$, \\ Thomas I. F. H. Cremers ${ }^{4,5,6}$ and Ben H. C. Westerink ${ }^{5,6}$ \\ ${ }^{1}$ Institute of Molecular Physiology and Genetics, Centre for Biosciences, Slovak Academy of Sciences, Bratislava, Slovakia \\ ${ }^{2}$ Institute of Experimental Endocrinology, Biomedical Research Center, Slovak Academy of Sciences, Bratislava, Slovakia \\ ${ }^{3}$ Faculty of Natural Sciences, University of Ss. Cyril and Methodius, Trnava, Slovakia \\ ${ }^{4}$ Brains On-Line BV, Groningen, the Netherlands \\ ${ }^{5}$ Faculty of Science and Engineering, University of Groningen, Groningen, the Netherlands \\ ${ }^{6}$ Brains On-Line US LLC, San-Francisco, California, USA
}

\begin{abstract}
It was previously reported that adenosine-2A $\left(\mathrm{A}_{2 \mathrm{~A}}\right)$ receptors interact with dopamine-2 $\left(D_{2}\right)$ receptors on a molecular level. The aim of the current study was to investigate the functional output of this interaction. In vivo microdialysis was used to assess the effects of an antagonist of $\mathrm{A}_{2 \mathrm{~A}}$ receptors, ZM 241385, and an antagonist of $\mathrm{D}_{2}$ receptors haloperidol, either alone or in combination, on brain catecholamine levels. It was found that ZM 241385 did not alter catecholamine levels by its own, but potentiated haloperidol-induced dopamine and norepinephrine release in the nucleus accumbens and prefrontal cortex, respectively. In vivo electrophysiology was used to assess the effect of an agonist (CGS 216820) and an antagonist (ZM 241385) of $\mathrm{A}_{2 \mathrm{~A}}$ receptors on the excitability of dopamine and norepinephrine neurons. It was found that CGS 216820 dose-dependently inhibited dopamine and norepinephrine neurons and ZM 241385 reversed this inhibition. In conclusion, those $\mathrm{A}_{2 \mathrm{~A}}$ receptors modulate brain catecholamine transmission, and this modulation is mediated, at least in part, via the regulation of excitability of norepinephrine and dopamine neurons. The ability of antagonists of $\mathrm{A}_{2 \mathrm{~A}}$ receptors to potentiate the effect of haloperidol on brain norepinephrine and dopamine levels may enhance its clinical efficacy as an antipsychotic drug.
\end{abstract}

Key words: Adenosine-2A receptors - Antipsychotic drugs - Dopamine-2 receptors - alpha-1/2adrenergic receptors - Electrophysiology — Microdialysis

\section{Introduction}

Adenosine, or (2R, 3R, 4S, 5R)-2-(6-amino-9H-purin-9-yl)5-(hydroxymethyl) oxolane-3, 4-diol, is a nucleoside composed of a purine nucleotide adenine and ribose. Adenosine plays an important role in multiple biological processes. As a part of adenosine triphosphate (ATP), it mediates bioenergetical processes in biological cells. In neurons, ATP supplies the energy for the storage of molecules of neurotransmitters to the synaptic vesicles by vesicular neurotransmitter

Correspondence to: Eliyahu Dremencov, Institute of Molecular Physiology and Genetics, Centre for Biosciences, Slovak Academy of Sciences, Dúbravská cesta 9, 84005 Bratislava, Slovakia E-mail: Eliyahu.Dremencov@savba.sk transporters (Takeda and Ueda 2017). During this process, ATP is metabolized to adenosine and its mono (AMP)- and diphosphates (ADP). These products of ATP hydrolysis are also stored in the synaptic vesicles (Cunha et al. 1996a).

Adenosine is not only co-released with other neurotransmitters as a side product of ATP hydrolysis, but also plays an important role in neuronal transmission (Cunha et al. 1996b). There are four known subtypes of adenosine receptors: the $G a_{I}$-protein-coupled $A_{1}$ and $A_{3}$ receptors and $\mathrm{Ga}_{S^{-}}$coupled $\mathrm{A}_{2 \mathrm{~A}}$ and $\mathrm{A}_{2 \mathrm{~B}}$ receptors (Krügel 2016). The $A_{2 A}$ and $A_{2 B}$ receptors are expressed on different types of brain neurons and glial cells. The $\mathrm{A}_{2 \mathrm{~B}}$ receptors are widely distributed across the brain, while $\mathrm{A}_{2 \mathrm{~A}}$ are almost exclusively expressed in the striatum, hippocampus, and prefrontal cortex (PFC) (Sebastiao and Ribeiro 1996). The $A_{2 A}$ receptors 
play an important role in the regulation of neuronal activity in the limbic areas of the brain. It was reported that agonists of $\mathrm{A}_{2 \mathrm{~A}}$ receptors stimulate glutamate and acetylcholine release, depolarize neurons in hippocampus and striatum, and inhibit GABA release in the PFC (Cunha et al. 1996c).

It was shown that $\mathrm{A}_{2 \mathrm{~A}}$ receptors interact with dopamine (DA) $\mathrm{D}_{2}$ receptors (Ferre et al. 1991a, 1991b). The $\mathrm{Ga}_{\mathrm{S}^{-}}$ coupled $\mathrm{A}_{2 \mathrm{~A}}$ receptors form a dimmer with $\mathrm{Ga}_{\mathrm{I}}$-coupled $\mathrm{D}_{2}$ receptors. The $\mathrm{A}_{2 \mathrm{~A}}-\mathrm{D}_{2}$ dimmer couples to $\mathrm{Ga} Q \mathrm{Q} / \mathrm{Z}$-protein and activates calcium- rather than cAMP-dependent signal transduction pathways. It has been suggested that $\mathrm{A}_{2 \mathrm{~A}}-\mathrm{D}_{2}$ interaction plays an important role in the excitatory effect of $A_{2 A}$ receptor on the neuronal circuits (Fuxe et al. 2014). Since DA system in general and $\mathrm{D}_{2}$ receptors in particular are essential in schizophrenia and Parkinson disease, it is possible that $\mathrm{A}_{2 \mathrm{~A}}$ receptors are also involved in pathophysiology and treatment of these disorders. Indeed, it was reported that an antagonist of $\mathrm{A}_{2 \mathrm{~A}}$ receptors, ZM 241385, potentiates the stimulatory effect of L-DOPA, a dopamine precursor and a first-choice drug for the treatment of Parkinson disease, on extracellular DA levels in the rat striatum (Golembiowska and Dziubina 2004, 2012a, 2012b). Other studies reported a potent anti-cataleptic effect of ZM 241385 and other antagonist of $\mathrm{A}_{2 \mathrm{~A}}$ receptors (Kanda et al. 1994; Shiozaki et al. 1999; Varty et al. 2008; Trevitt et al. 2009; Collins et al. 2012; Atack et al. 2014). However, the exact mechanism of $A_{2 A}$ receptor-mediated modulation of brain DA transmission was not yet investigated.

It was also reported that dipyridamole, an adenosine reuptake inhibitor, potentiates the effect of haloperidol, an antagonist of $\mathrm{D}_{2}$ receptors and an antipsychotic drug, on the negative and cognitive symptoms of schizophrenia (Akhondzadeh et al. 2000). Knockout mice lacking $\mathrm{A}_{2 \mathrm{~A}}$ receptors demonstrated cognitive and behavioral impairments which resembled the negative symptoms of schizophrenia (Moscoso-Castro et al. 2016). Because of the role of limbic norepinephrine (NE) in the negative and cognitive symptoms of schizophrenia (Yamamoto and Hornykiewicz 2004), it is possible that $\mathrm{A}_{2 \mathrm{~A}}$ receptors modulate NE transmission. Although the modulatory effect of $\mathrm{A}_{2}$ receptors on $\mathrm{NE}$ transmission was previously observed in the spinal cord (Aran and Proudfit 1990a, 1990b), their effect on limbic NE pathways was not yet investigated.

The present study aimed to investigate the neurophysiological mechanism of the modulatory effect of $\mathrm{A}_{2 \mathrm{~A}}$ receptors on limbic DA and $\mathrm{NE}$ neurotransmission. Using in vivo microdialysis, the effects of an antagonist of $\mathrm{A}_{2 \mathrm{~A}}$ receptors, ZM 241385, and an antagonist of $D_{2}$ receptors, haloperidol, and their combination, on DA and NE release in the nucleus accumbens (NAcc) and prefrontal cortex (PFC) was examined. Using in vivo electrophysiology, the effects of an agonist of $\mathrm{A}_{2 \mathrm{~A}}$ receptors, CGS 216820, and their antagonist ZM 241385 on the excitability of DA neurons of the ventral tegmental area (VTA) and NE neurons of the locus coeruleus (LC) were investigated.

\section{Materials and Methods}

\section{Animals}

Male Wistar rats (300-350 g; Harlan, Horst, the Netherlands) were used for the experiments. The animals were housed in plastic cages $(30 \times 30 \times 40 \mathrm{~cm})$ and had access to food and water ad libitum. Experiments were conducted in accordance with the Directive 2010/63/EU of the European Parliament and of the Council of the European Union and were approved by the Animal Care Committee of the University of Groningen.

\section{Surgery}

Rats were anesthetized with isoflurane $\left(2 \%, 800 \mathrm{ml} / \mathrm{min}_{2}\right)$. Bupivacaine/adrenaline solution was used for local analgesia. The animals were placed in a stereotaxic frame (David Kopf Instruments, Tujunga, CA). $3 \mathrm{~mm}$ hole was drilled in the skull to allow insertion of microdialysis probe or electrode (for PFC: $3.4 \mathrm{~mm}$ anterior to bregma and $0.8 \mathrm{~mm}$ lateral to midline; for NAcc: $2.0 \mathrm{~mm}$ anterior to bregma and $1.2 \mathrm{~mm}$ lateral to midline; for LC: $8.2 \mathrm{~mm}$ posterior to bregma and $1.2 \mathrm{~mm}$ lateral to midline; for VTA: 5.0 posterior to bregma and 0.7 lateral to midline) (Paxinos and Watson 2014).

\section{Microdialysis}

Microdialysis experiments were performed as previously described (Dremencov et al. 2004a, 2005, 2011; Westerink and Cremers 2007; Allers et al. 2010; Cremers et al. 2010; Bloms-Funke et al. 2011; Flik et al. 2011, 2015; Yamada et al. 2013; Visser et al. 2015). I-shaped probes (Hospal AN 69 membrane, Brainlink, Groningen, the Netherlands) were inserted in the PFC (5.0 mm dorsal from the brain surface, 4 $\mathrm{mm}$ exposed surface probe) or NAcc (7.9 $\mathrm{mm}$ dorsal from the brain surface, $1.5 \mathrm{~mm}$ exposed surface probe); experiments were carried out 24-48 hours after surgery. The microdialysis probes were connected with flexible polyether ether ketone (PEEK) tubes to microperfusion pumps (CMA 102). The dialysis probes were perfused with a Ringer buffer containing $147 \mathrm{mM} \mathrm{NaCl}, 3.0 \mathrm{mM} \mathrm{KCl}, 1.2 \mathrm{mM} \mathrm{CaCl}_{2}$, and $1.2 \mathrm{mM}$ $\mathrm{MgCl}_{2}$, at a flow rate of $1.5 \mu \mathrm{l} / \mathrm{min}$. Microdialysis samples were collected every 20 minutes. After completion of the experiments rats were sacrificed and brains were removed and stored for three days in paraformaldehyde solution (4\% $\mathrm{m} / \mathrm{v}$ ). The position of each probe was verified histologically according to Paxinos and Watson (2014), by making coronal sections of the brain. 
Analysis of monoamines levels in dialysates

Neurotransmitters were separated using high-performance liquid chromatography (HPLC). Their concentrations were determined using tandem mass spectrometric detection and quantified by area under the peak integration method. Two microliters of an internal standard containing $100 \mathrm{nM}$ of NE and DA were added to original $20 \mu$-samples. The resulting $22 \mu \mathrm{l}$ mixes were derivatized for 1 minute with $40 \mu \mathrm{l}$ of the derivatization reagent containing $8 \mathrm{mg}$ of SymDAQ dissolved in $5 \mathrm{ml}$ of $0.5 \mathrm{M} \mathrm{NaHCO}_{3}, 4.5 \mathrm{ml}$ of ultrapure water, $0.5 \mathrm{ml}$ of methanol, and $20 \mathrm{ml}$ of 2 -mercaptoethanol. After derivatization, $40 \mu$ lof each sample were injected by an automatic sampler device (Sil-10 ADvp auto-sampler, Shimadzu, Tokyo, Japan). Chromatographic separation was performed on a reversed-phase column $(150 \times 2.0 \mathrm{~mm}$ Synergi MAXRP, $4 \mathrm{~mm}$, Phenomenex, Torrance, CA, USA). Samples were eluted using a linear gradient of $5-70 \%$ of acetonitrile with $0.1 \%$ formic in ultrapure water with $0.1 \%$ formic acid for 6 minutes at a flow rate of $0.3 \mathrm{ml} /$ minute. The flow was mixed (postcolumn) with a makeup flow of $0.15 \mathrm{ml} /$ minute of the mobile phase (acetonitrile with $0.1 \%$ formic acid in ultrapure water with $0.1 \%$ formic acid), and directed to mass spectrometer (API 4000, Applied Biosystems, Foster City, CA, USA). Mass spectra were determined in multi-reaction mode (MRM) for 3-7 minutes (Dremencov et al. 2004a, 2005, 2011; Westerink and Cremers 2007; Allers et al. 2010; Cremers et al. 2010; Bloms-Funke et al. 2011; Flik et al. 2011, 2015; Yamada et al. 2013; Visser et al. 2015).

\section{Electrophysiology}

Extracellular single-unit in vivo electrophysiological recordings were performed, as previously described (Dremencov et al. 2007a, 2007b, 2009, 2017; Flik et al. 2011). Surgical anesthesia was maintained using propofol (20\%) continuously administered intravenously (i.v., via a catheter placed in the lateral tail vein) at a rate $20 \mu \mathrm{l} / \mathrm{min}$ (for $300 \mathrm{~g}$ rat) by a microperfusion pump (CMA 102, Stockholm, Sweden). The body temperature was maintained between $36^{\circ} \mathrm{C}$ and $37^{\circ} \mathrm{C}$ using a heating pad (Gaymor Instruments, Orchard Park, NY, USA). Glass-pipettes (TW100F-3, WPI; FL, USA) were pulled to a fine tip with a diameter of $\sim 1 \mu \mathrm{m}$ with a programmable puller (Sutter, Novato, CA, USA) and filled with a $2 \mathrm{M}$ sodium chloride $(\mathrm{NaCl})$ solution. The impedances of electrodes ranged between 8 and $10 \mathrm{M} \Omega$. The pipettes were lowered into the LC or VTA using a hydraulic micropositioner (David Kopf Instruments, Tujunga, CA). Signals were amplified using an 1800 Microelectrode AC amplifier (A-M systems, Inc.; WA, USA). The signal was subsequently fed into a Micro 1401 ADC interface unit and recorded on a computer using the Spike-2 software package (CED; Cambridge, UK). The NE and DA neurons were identified by: (1) their location (NE neurons of the LC: $8.0-8.3 \mathrm{~mm}$ posterior to bregma, $1.2-1.4 \mathrm{~mm}$ lateral to the midline, and 5.5-7.5 $\mathrm{mm}$ ventral to the brain surface; DA neurons of the VTA: $4.5-5.5 \mathrm{~mm}$ posterior to bregma, $0.6-0.8 \mathrm{~mm}$ lateral to the midline, and $7.0-8.5 \mathrm{~mm}$ ventral to the brain surface); (2) firing pattern (NE neurons: regular firing rate of $0.5-5.0 \mathrm{~Hz}$, positive action potential of long duration of $0.8-1.2 \mathrm{~ms}$ and a characteristic burst discharge in response to nociceptive pinch of the contralateral hind paw; DA neurons: slow irregular firing-rate of $0.5-10 \mathrm{~Hz}$, mixed single spike and burst firing, tri-phasic action potentials with a dominant positive component, a minor one with duration over $2.5 \mathrm{~ms}$ and a "notch" often present on the initial rising phase and a minimum $1.1 \mathrm{~ms}$ duration from action potential initiation to the negative trough); (3) their response to the specific antagonist (NE neurons: $\alpha_{2}$-adrenergic receptor agonist clonidine; DA neurons: $\mathrm{D}_{2}$ receptor agonist apomorphine).

\section{Drugs}

CGS 216820, ZM 241385, apomorphine, and clonidine were purchased from Tocris Biosciences. CGS 216820 and ZM 241385 were dissolved in 10\% solution of dimethyl sulfoxide (DMSO) in distilled water at the concentrations 0.5 and $1.0 \mathrm{mg} / \mathrm{ml}$, respectively. Apomorphine and clonidine were dissolved in distilled water at the concentrations 0.02 and $0.02 \mathrm{mg} / \mathrm{ml}$, respectively. Haloperidol was dissolved in $10 \%$ tartaric acid at $\mathrm{pH}=1$ and then in distilled water at the concentration $0.25 \mathrm{mg} / \mathrm{ml}$; the $\mathrm{pH}$ of the final solution was close to seven.

\section{Animal handling}

The animals for in vivo microdialysis experiments were randomly divided into four groups: (1) vehicle+vehicle, (2) ZM 241385+vehicle, (3) vehicle+haloperidol, and (4) ZM 241385+haloperidol. The first group was administered $2.0 \mathrm{ml} / \mathrm{kg} 10 \% \mathrm{DMSO}$ in distilled water (intraperitoneally (i.p.); $40 \mathrm{~min}$ after the beginning of the experiment) and $2.0 \mathrm{ml} / \mathrm{kg}$ of distilled water (i.p.; $60 \mathrm{~min}$ after DMSO administration). The second group was administered $1.0 \mathrm{mg} / \mathrm{kg}$ of ZM 2431385 (i.p.; 40 min after the beginning of the experiment) and $2.0 \mathrm{ml} / \mathrm{kg}$ of distilled water (i.p.; 60 min after ZM 241385 administration). The third group was administered $2.0 \mathrm{ml} / \mathrm{kg}$ of $10 \%$ DMSO in distilled water (i.p.; $40 \mathrm{~min}$ after the beginning of the experiment) and $0.50 \mathrm{mg} / \mathrm{kg}$ of haloperidol (i.p.; 60 min after DMSO administration). The fourth group was administered $1.0 \mathrm{mg} / \mathrm{kg}$ of ZM 2431385 (i.p.; $40 \mathrm{~min}$ after the beginning of the experiment) and $0.5 \mathrm{mg} / \mathrm{kg}$ of haloperidol (i.p.; 60 min after ZM 241385 administration).

The animals participating in in vivo electrophysiology experiments were randomly divided into two groups. The first group was used to assess the effect of consecutive 
administration of vehicle, CGS 216820, ZM 241385, and apomorphine on the excitability of DA neurons in the VTA. The second group was used to assess the effect of consecutive administration of vehicle, CGS 216820, ZM 241385, and clonidine on the excitability of NE neurons in the LC. During the electrophysiology experiments, when a DA or NE neuron was identified and recorded for at least $100 \mathrm{~s}$, vehicle (10\% DMSO in distilled water; $1 \mathrm{ml} / \mathrm{kg}$ ), was administered intravenously (i.v.; via catheter placed in the lateral tail vein). Afterward, CGS 216820 was administered at cumulative doses of $0.05,0.15$, and $0.50 \mathrm{mg} / \mathrm{kg}$ (at least 100, 200, and $300 \mathrm{~s}$ after vehicle administration), respectively, and after the firing activity of the neuron, was stabilized from the previous injection. Following CGS 216820, ZM 241385 was administered at cumulative doses of $0.10,0.30$, and $1.00 \mathrm{mg} / \mathrm{kg}$ (at least 100, 200, and $300 \mathrm{~s}$ after last CGS 216820 administration, respectively, and after the firing activity of the neuron, was stabilized from the previous injection). One hundred minutes after the last ZM 241385 injection, apomorphine (0.02 mg/kg; for DA neurons) or clonidine $(0.02 \mathrm{mg} / \mathrm{kg}$; for NE neurons) were administered.

\section{Statistical analyses}

For electrophysiology experiments, the mean firing rate recorded during 100 consecutive seconds, after the stabilization of firing activity, was considered as a baseline; for microdialysis experiments, mean DA or NE concentration in four consecutive fractions, with variability less than $50 \%$, was taken as baseline. All data are expressed as mean \pm SEM $\%$ of baseline. One-way analysis of variance (ANOVA) for repeated measurements, followed by Bonferroni post-hoc test, was used for electrophysiology experiments. Two-way (time, versus treatment group) ANOVA for repeated measurements, followed by Bonferroni post-hoc test, was used for microdialysis experiments. The level of significance was set as $p<0.05$.

\section{Results}

Basal levels of catecholamines and basal firing activity of catecholamine-secreting neurons

The basal DA levels were $1.29 \pm 0.34 \mathrm{nM}$ in the NAcc and $0.15 \pm 0.03 \mathrm{nM}$ in the PFC. The basal NE levels were 2.95 $\pm 0.78 \mathrm{nM}$ in the NAcc and $1.42 \pm 0.48 \mathrm{nM}$ in the PFC. The basal firing rates of DA neurons of the VTA and NE neurons of the LC were $6.28 \pm 1.45$ and $2.90 \pm 1.23 \mathrm{~Hz}$, respectively.

\section{ZM 241385 potentiated haloperidol-induced increase in extracellular DA levels in the NAcc, but not in the PFC}

ZM 241385, administered alone, did not alter extracellular DA levels in the NAcc or in the PFC. Haloperidol administration resulted in a 200\%-increase in DA levels in the NAcc. Co-administration of ZM 241385 and halo-
A

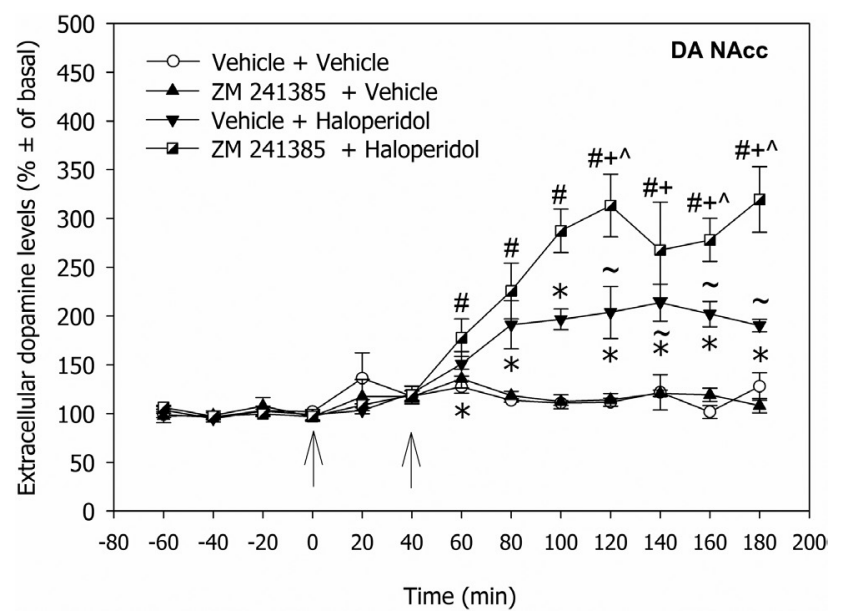

B

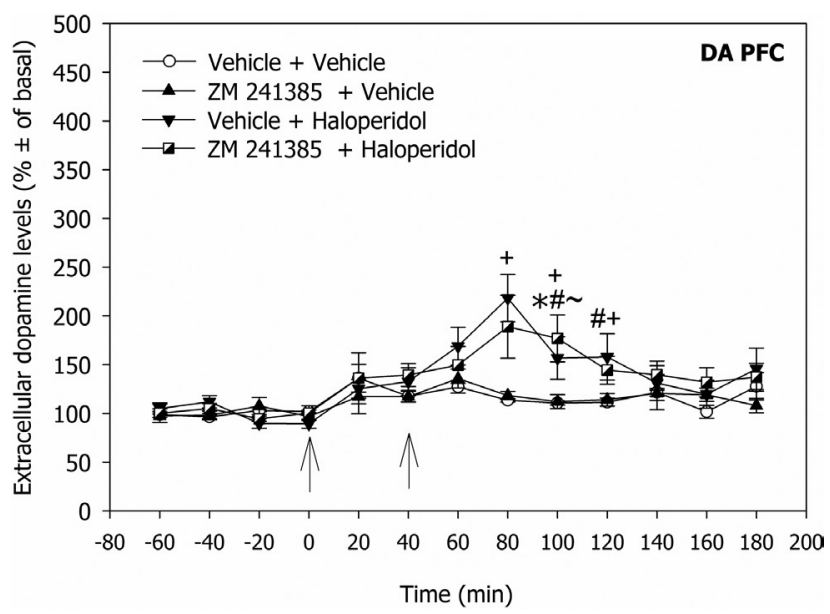

Figure 1. Effects of ZM 241385, haloperidol, and their combination on extracellular dopamine (DA) levels in the rat nucleus accumbens (NAcc; A) and prefrontal cortex (PFC; B). The first arrow marks the administration of ZM 241385 (1.0 mg/kg, i.p.) or its vehicle (10\% DMSO in distilled water, $2.0 \mathrm{ml} / \mathrm{kg}$, i.p.). The second arrow marks the administration of haloperidol $(0.5 \mathrm{mg} / \mathrm{kg}$, i.p.) or its vehicle (2.0 ml/ $\mathrm{kg}$ distilled water, i.p.). ${ }^{*} \mathrm{p}<0.05$ vs. baseline, haloperidol-administered rats; $\# \mathrm{p}<0.05$ vs. baseline, ZM $241385+$ haloperidol-administered rats; $\sim \mathrm{p}<0.05 v s$. vehicle, haloperidol-administered rats; $+\mathrm{p}<0.05 v s$. vehicle, ZM 241385+haloperidol-administered rats; $\wedge \mathrm{p}<0.05$ vs. haloperidol, ZM 241385+haloperidol-administered rats; Bonferoni post-hoc test. 
A

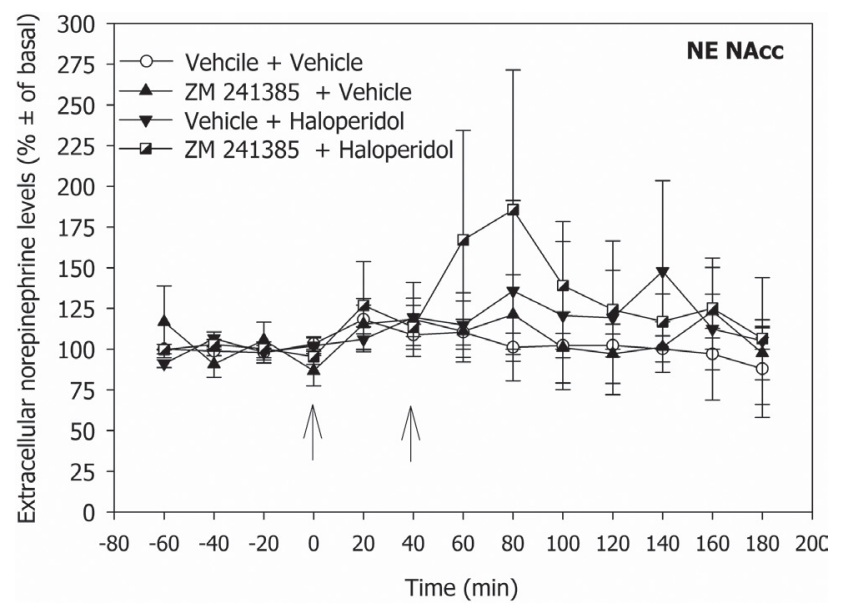

B

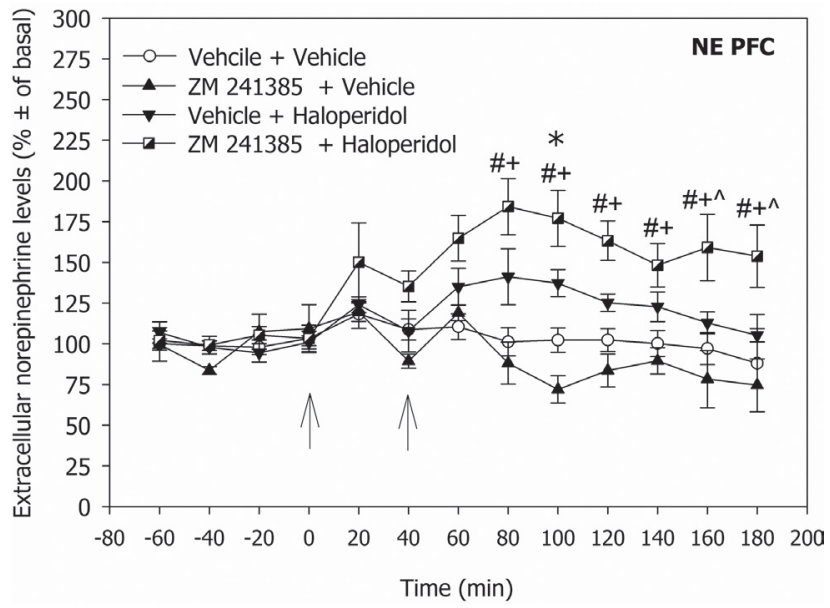

Figure 2. Effects of ZM 241385, haloperidol, and their combination on extracellular norepinephrine levels in the rat nucleus accumbens (NAcc; A) and prefrontal cortex (PFC; B). The first arrow marks the administration of ZM 241385 (1.0 mg/kg, i.p.) or its vehicle (10\% DMSO in distilled water, $2.0 \mathrm{ml} / \mathrm{kg}$, i.p.). The second arrow marks the administration of haloperidol $(0.5 \mathrm{mg} / \mathrm{kg}$, i.p.) or its vehicle (2.0 ml/ $\mathrm{kg}$ distilled water, i.p.). $\# p<0.05$ vs. baseline, ZM 241385+haloperidol-administered rats; $\wedge \mathrm{p}<0.05 v s$. vehicle, haloperidol-administered rats; $+\mathrm{p}<0.05$ vs. vehicle, ZM 241385+haloperidol-administered rats; Bonferoni post-hoc test.

peridol resulted in a 500\%-increase in extracellular DA levels in the NAcc, which was higher than the $200 \%$-increase in extracellular DA levels produced by haloperidol administered alone (Fig. 1A). Similar 200\%-increase in cortical DA levels was observed in rats administered with haloperidol alone or with ZM 241385 and haloperidol (Fig. 1B). The details of statistical analysis are provided in the Table 1.

Table 1. Details of statistical analysis

\begin{tabular}{|c|c|c|c|c|c|c|c|c|}
\hline \multirow{2}{*}{ Experiment } & \multirow{2}{*}{ Group } & \multirow{2}{*}{$n$} & \multicolumn{3}{|c|}{ ANOVA F-values } & \multicolumn{3}{|c|}{ ANOVA p-values } \\
\hline & & & Time & Treat & Inter & Time & Treat & Inter \\
\hline $\begin{array}{l}\text { Effects of ZM } 241385 \text { and } \\
\text { haloperidol on extracellular DA } \\
\text { levels in the NAcc }\end{array}$ & $\begin{array}{l}\text { Vehicle+vehicle } \\
\text { ZM 241385+vehicle } \\
\text { Vehicle+haloperidol } \\
\text { ZM 241385+haloperidol }\end{array}$ & $\begin{array}{l}5 \\
4 \\
5 \\
4\end{array}$ & 2.55 & 7.04 & 1.77 & $<0.05$ & $<0.005$ & $<0.05$ \\
\hline $\begin{array}{l}\text { Effects of ZM } 241385 \text { and } \\
\text { haloperidol on extracellular DA } \\
\text { levels in the PFC }\end{array}$ & $\begin{array}{l}\text { Vehicle+vehicle } \\
\text { ZM 241385+vehicle } \\
\text { Vehicle+haloperidol } \\
\text { ZM 241385+haloperidol }\end{array}$ & $\begin{array}{l}5 \\
4 \\
5 \\
5\end{array}$ & 4.33 & 4.02 & N.S. & $<0.001$ & $<0.05$ & NS \\
\hline $\begin{array}{l}\text { Effects of ZM } 241385 \text { and } \\
\text { haloperidolon extracellular NE } \\
\text { levels in the NAcc }\end{array}$ & $\begin{array}{l}\text { Vehicle+vehicle } \\
\text { ZM 241385+vehicle } \\
\text { Vehicle+haloperidol } \\
\text { ZM 241385+haloperidol }\end{array}$ & $\begin{array}{l}4 \\
4 \\
4 \\
4\end{array}$ & NS & NS & NS & NS & NS & NS \\
\hline $\begin{array}{l}\text { Effects of ZM } 241385 \text { and } \\
\text { haloperidolon extracellular NE } \\
\text { levels in the PFC }\end{array}$ & $\begin{array}{l}\text { Vehicle+vehicle } \\
\text { ZM 241385+vehicle } \\
\text { Vehicle+haloperidol } \\
\text { ZM 241385+haloperidol }\end{array}$ & $\begin{array}{l}5 \\
4 \\
5 \\
6\end{array}$ & 4.02 & 6.88 & 2.12 & $<0.001$ & $<0.005$ & $<0.005$ \\
\hline $\begin{array}{l}\text { Effects of CGS } 21680 \text { and ZM } 241385 \\
\text { on the firing activity of DA neurons }\end{array}$ & $\begin{array}{l}\text { Vehicle+CGS21680+ZM } \\
241385+\text { Apomorphine }\end{array}$ & 5 & 8.13 & NA & NA & $<0.001$ & NA & NA \\
\hline $\begin{array}{l}\text { Effects of CGS } 21680 \text { and ZM } 241385 \\
\text { on the firing activity of NE neurons }\end{array}$ & $\begin{array}{l}\text { Vehicle+CGS21680+ZM } \\
\text { 241385+Clonidine }\end{array}$ & 5 & 6.36 & NA & NA & $<0.001$ & NA & NA \\
\hline
\end{tabular}

DA, dopamine; NE, norepinephrine; PFC, prefrontal cortex; NAcc, nucleus accumbens; Treat, treatment; Inter, time $\times$ treatment interaction; $n$, number of subjects; NS, not significant; NA, not applicable. 
ZM 241385 potentiated haloperidol-induced increase in extracellular NE levels in the PFC, but not in the NAcc

ZM 241385, haloperidol, or their combination did not significantly alter extracellular NE levels in the NAcc (Fig. 2A). ZM 241385, administered alone, did not alter cortical NE levels as well. Haloperidol, administered by its own, slightly increased NE levels in the PFC (150\% of baseline). However, co-administration of ZM 241385 and haloperidol produced significantly greater 200\%-increase in extracellular NE levels in the PFC (Fig. 2B). The numbers of the animals and details of statistical analysis are provided in the Table 1.

\section{CGS 21680 inhibited DA neuronal firing activity in the} $V T A$, and ZM 241385 reversed this inhibition

The i.v. administration of CGS 21680 significantly and dose-dependently inhibited the firing activity of DA neurons. Subsequent administration of ZM 241385 partially reversed CGS 21680-induced inhibition of DA neurons, in a dose-dependent manner. The subsequent administration of apomorphine inhibited DA neurons in the VTA again (Fig. 3). The details of statistical analysis are provided in the Table 1.

CGS 21680 inhibited NE neuronal firing activity in the LC, and ZM 241385 reversed this inhibition

The i.v. administration of CGS 21680 significantly and dose-dependently inhibited the firing activity of NE neurons. Subsequent administration of ZM 241385 partially reversed CGS 21680-induced inhibition of NE neurons, in a dose-dependent manner. The subsequent administration of clonidine inhibited NE neurons in the LC again (Fig. 4). The numbers of the animals and details of statistical analysis are provided in the Table 1.

\section{Discussion}

The results of the current study demonstrated that selective antagonist of $\mathrm{A}_{2 \mathrm{~A}}$ receptors, ZM 241385, administered alone, did not alter extracellular levels of NE or DA in the NAcc or in the PFC. However, ZM 241385 potentiated haloperidol-induced increase in DA levels in the NAcc and $\mathrm{NE}$ levels in the PFC. Selective agonist of $\mathrm{A}_{2 \mathrm{~A}}$ receptors, CGS 21680, dose-dependently inhibited the firing activity of DA neurons of the VTA and NE neurons of the LC. The CGS 21680-induced inhibition of DA and NE neurons was partially reversed by ZM 241385. DA and NE neurons were inhibited after the subsequent administration of apomorphine and clonidine, respectively.

Our finding that an acute administration of haloperidol increased extracellular levels of DA in the NAcc and PFC, and of NE in the PFC, is in line with previous studies (Prus et al. 2007; Madularu et al. 2014; Tanda et al. 2015). The accumbal levels of NE were not affected by haloperidol, as previously reported (Zhang et al. 2000).

An acute systemic administration of the selective antagonist of $A_{2 A}$ receptors, $Z M$ 241385, did not alter extracellular levels of DA in the NAcc and PFC. Similarly, Gołembiowska and Dziubina (2004) reported that intra-striatal administra-
A

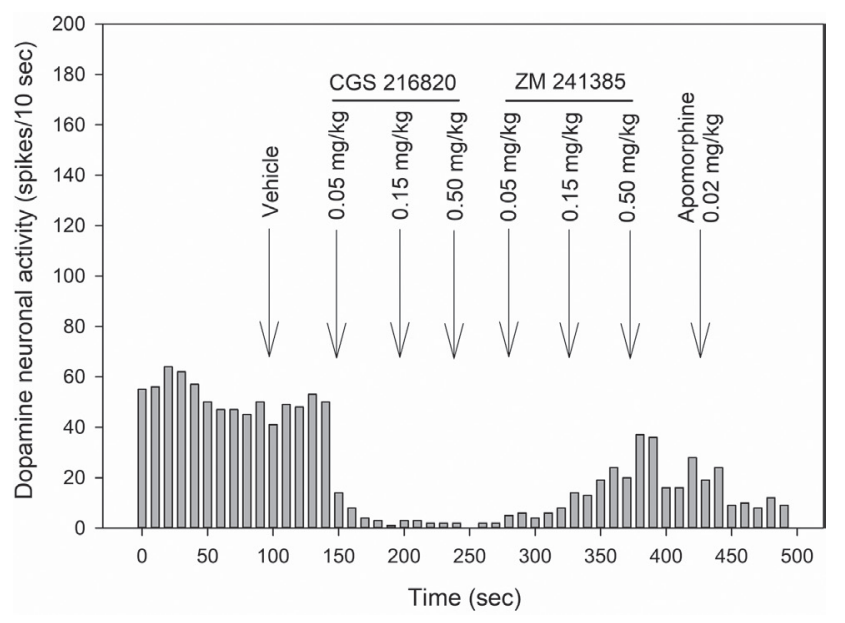

B

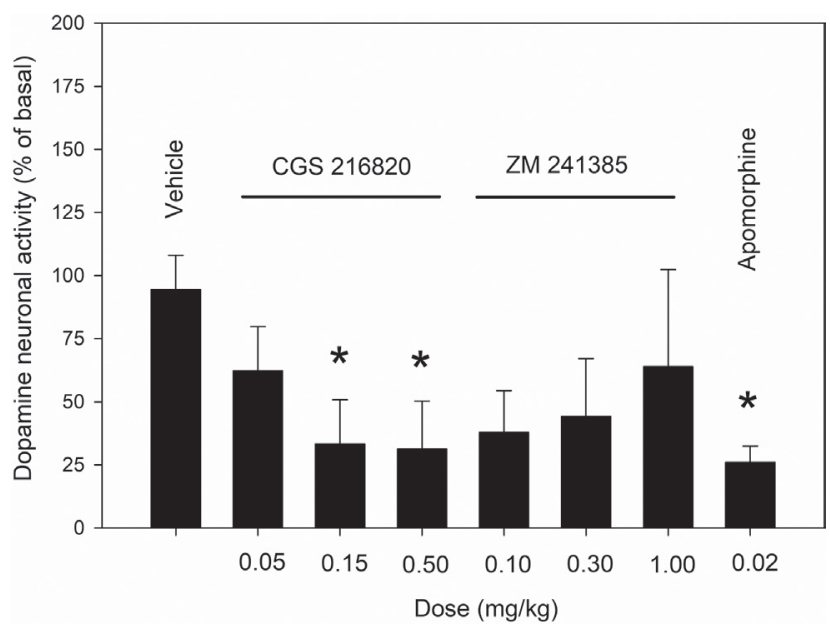

Figure 3. Effects of CGS 216820, ZM 241385, and apomorphine on dopamine (DA) neuronal firing activity in the rat ventral tegmental area (VTA). A. Representative recording from a VTA DA neuron. Arrows indicate the times of administration of vehicle, CGS 216820 (0.05, 0.15, and $0.50 \mathrm{mg} / \mathrm{kg}$, i.v.), ZM 241385 (0.10, 0.30, and $1.00 \mathrm{mg} / \mathrm{kg}$, i.v.), and clonidine $(0.02 \mathrm{mg} / \mathrm{kg}$, i.v.). B. Summary effect of CGS 216820, ZM 241385, and apomorphine on DA neuronal firing activity in the VTA; ${ }^{\star} \mathrm{p}<0.05 v s$. baseline, Bonferoni post-hoc test. 
A

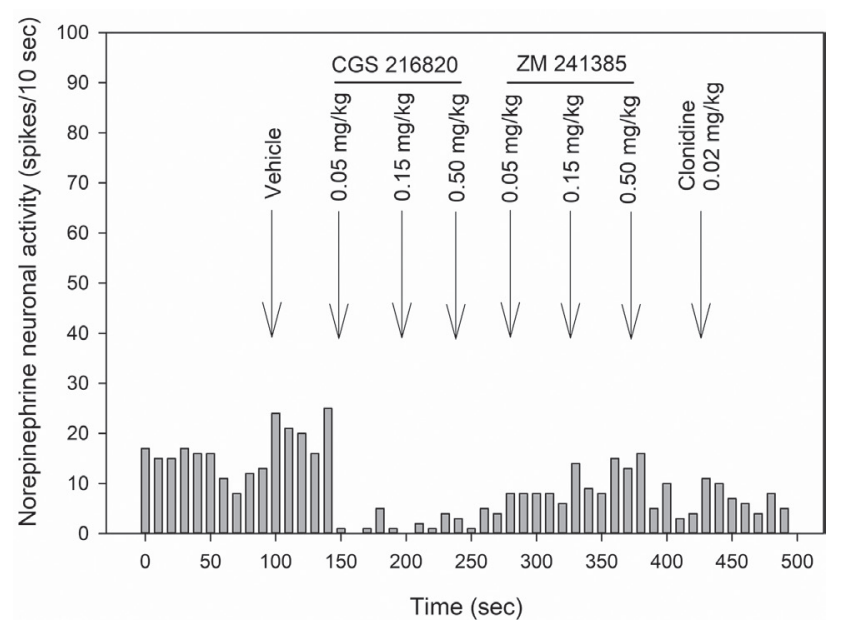

B

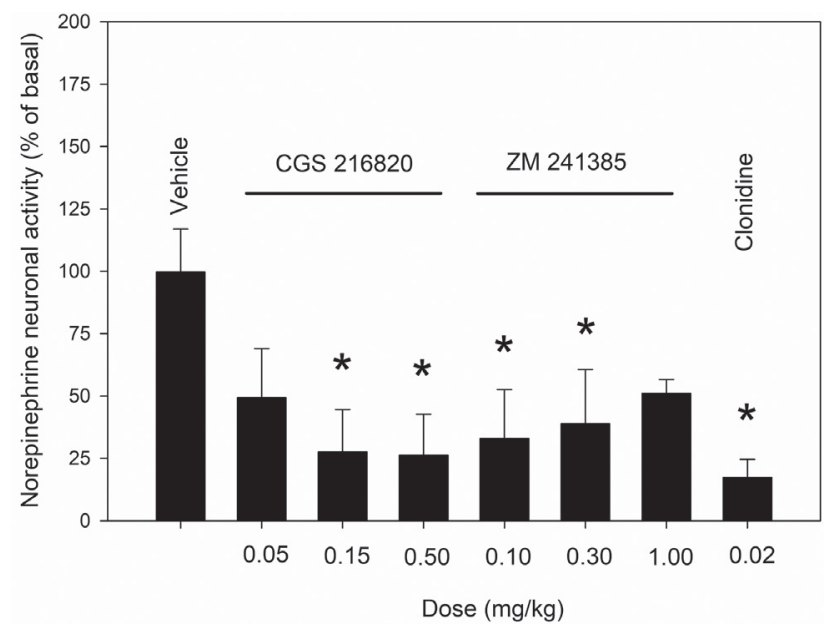

Figure 4. Effects of CGS 216820, ZM 241385, and clonidine on norepinephrine (NE) neuronal firing activity in the rat locus coeruleus (LC). A. Representative recording from a LC NE neuron. Arrows indicate the times of administration of vehicle, CGS 216820 $\left(0.05,0.15\right.$, and $0.50 \mathrm{mg} / \mathrm{kg}$, i.v.), ZM $241385\left(0.10,0.30\right.$, and $\left.1.00 \mathrm{mg} / \mathrm{kg}, i . v_{\text {. }}\right)$, and apomorphine $(0.02 \mathrm{mg} / \mathrm{kg}$, i.v. $)$. B. Summary effect of CGS 216820, ZM 241385, and apomorphine on NE neuronal firing activity in the LC; ${ }^{*} \mathrm{p}<0.05 v s$. baseline, Bonferoni post-hoc test.

tion of ZM 241385 did not alter local DA levels. Chronic systemic administration of ZM 241385 or of another antagonist of $\mathrm{A}_{2 \mathrm{~A}}$ receptors, CSC, did not alter striatal DA levels as well (Golembiowska and Dziubina 2012a). The novel antagonist of $A_{2 A}$ and $A_{1}$ receptors, JNJ-40255293, did not alter cortical and striatal DA levels as well (Atack et al. 2014). Interestingly, CSC increased striatal DA levels in rats pre-treated with the VMAT inhibitor reserpine, while ZM 241385 had no effect (Golembiowska and Dziubina 2012a, 2012b). However, it was reported that another antagonist of $\mathrm{A}_{2 \mathrm{~A}}$ receptors, KW6002, induced a robust increase in DA release in the NAcc (Harper et al. 2006). The difference between our results and Harper and colleagues' is likely due to the different techniques determining DA release and different ligand used to block $\mathrm{A}_{2 \mathrm{~A}}$ receptors. Specifically, in vivo microdialysis assessment of DA release in the NAcc was used in this study, in contrast to those authors' ex vivo measurement of [3H]-DA release from the NAcc slices. In this study, a highly selective antagonist of $\mathrm{A}_{2 \mathrm{~A}}$ receptors was used. The ligand used in Harper's study, although it has a robust $\mathrm{A}_{2 \mathrm{~A}}$ antagonistic property, also blocks adenosine $A_{1}$ receptors.

We have observed that the selective antagonist of $A_{2 A}$ receptors, ZM 241385, did not alter extracellular NE levels in the NAcc and PFC. Similarly, Carter (1997) reported that neither the agonist of $A_{2}$ receptors, CGS 21680, nor the $A_{1 / 2}$ antagonist caffeine, alter NE release in the rat hippocampus.

It was observed that the selective antagonist of $\mathrm{A}_{2 \mathrm{~A}}$ receptors, ZM 241385, potentiates haloperidol-induced increase in DA levels in the NAcc. Interestingly, ZM 241385 and CSC also potentiated L-DOPA-induced DA in the striatum of intact, but not DA-denervated rats. The potentiating effect of ZM 241385 and CSC on striatal DA release was also observed in reserpine-pretreated rats (Golembiowska and Dziubina 2004, 2012a, 2012b). It is possible that the mechanisms of $\mathrm{A}_{2 \mathrm{~A}}$-mediated potentiation haloperidol- and L-DOPAinduced DA release are complimentary. Both haloperidol and L-DOPA are increasing DA bioavailability: haloperidol by blocking of $\mathrm{D}_{2}$ receptors and subsequent activation of DA neurons, and L-DOPA by an increase in the synthesis of DA in the neurons. It is possible that antagonists of $\mathrm{A}_{2 \mathrm{~A}}$ receptors diminish the inhibitory effect of DA and/or potentiate the stimulatory effect of haloperidol on the excitability of DA neurons, via a mechanism involving dimerization of $\mathrm{A}_{2 \mathrm{~A}}$ and $\mathrm{D}_{2}$ receptors (Fig. 5).

The results of this study demonstrated that ZM 241385 potentiated the haloperidol-induced NE release in the PFC. It was previously reported that $\mathrm{A}_{2}$ receptors regulate $\mathrm{NE}$ neurotransmission in the spinal cord and this regulation play a role in the pain modulation (Aran and Proudfit 1990a). It was also suggested that $A_{2}$ receptors interact with $\alpha_{1^{-}}$and $\alpha_{2^{-}}$ adreneric ones (Aran and Proudfit 1990b). It has been shown that cortical $\alpha_{1}$-adrenoceptors have a stimulatory (Stone et al. 2007 ), and $\alpha_{2}$-adrenoceptors - an inhibitory effect on central NE neurotransmission (Shirokawa et al. 2003). Haloperidol is a potent $\mathrm{D}_{2}$ receptor antagonist with a minor affinity for $\alpha_{1^{-}}$(Richelson and Souder 2000) and $\alpha_{2}$-adrenoceptors (Richelson and Nelson 1984). It is possible that ZM 241385, via a mechanism involving dimerization of $\mathrm{A}_{2}$ and $\alpha_{1}$ - and/ 


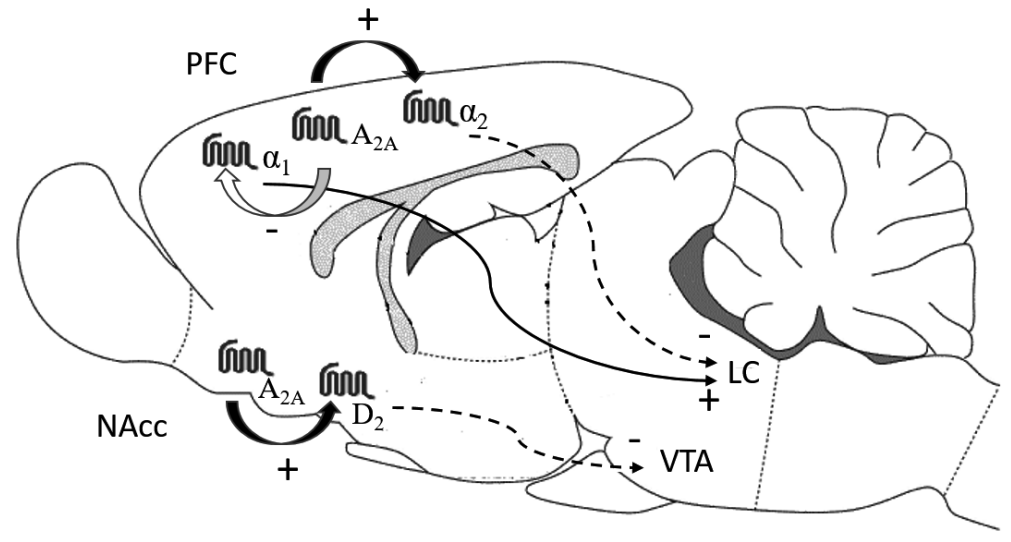

Figure 5. Interaction between adenosine, dopamine, and norepinephrine systems. PFC, prefrontal cortex; NAcc, nucleus accumbens; VTA, ventral tegmental area; $\mathrm{A}_{2 \mathrm{~A}}$, adenosine- $2 \mathrm{~A}$ receptors; $\mathrm{D}_{2}$, dopamine- 2 receptors; $\alpha_{1 / 2}$, alpha- $1 / 2$ adrenoceptors; “+” or solid line, excitatory pathway; “-” or dotted line, inhibitory pathway. or $\alpha_{2}$-adrenocpetors, diminishes the $\alpha_{1}$ - mediated inhibitory effect of haloperidol on NE transmission. Alternatively, haloperidol may stimulate the $\alpha_{2}$-adrenocpetor-mediated stimulatory effect of haloperidol in NE tone (Fig. 5). However, further studies should be performed to investigate molecular and functional interactions between adenosine and NE receptors in the brain.

Based on our finding and previous reports, it can be summarized that $\mathrm{A}_{2 \mathrm{~A}}$ receptors modulate $\mathrm{NE}$ and $\mathrm{DA}$ transmission in the brain. We performed in vivo electrophysiological experiments to examine whether this modulation involves an alteration of the firing activity of $\mathrm{NE}$ and DA neurons. We have wound that the selective agonist of $\mathrm{A}_{2 \mathrm{~A}}$ receptors, CGS 21680, dose-dependently inhibited the firing activity of NE neurons in the LC and DA neurons in the VTA and these inhibitions were reversed by ZM 241385, also in a dose-dependent mater. To our best knowledge, it was a first direct examination of the effect of $\mathrm{A}_{2 \mathrm{~A}}$ ligands of the excitability of catecholamine-secreting neurons in in vivo conditions.

It was, however, previously reported that CGS21680 facilitated the excitatory post-synaptic potentials (EPSPs) in hippocampal slices (Rebola et al. 2003) and potentiated metabotropic glutamate receptor-5 ( $\left.\mathrm{mGlu}_{5}\right)$-induced EPSPs is corticostriatal slices (Domenici et al. 2004). On the other hand, $\mathrm{D}_{2}$ - and $\mathrm{mGlu}_{5}$-induced EPSP is corticostriatal slices were diminished by ZM 241385 (Tozzi et al. 2011). Since striatal neurons negatively regulate DA neuronal firing activity in the VTA (Dremencov et al. 2006), it is possible that the ability of CGS 21680 and ZM 241385 to modulate the excitability of DA neurons in the VTA is mediated, at least in part, via the activation and blocking of $\mathrm{A}_{2 \mathrm{~A}}$ receptors in the striatum. Since $\mathrm{A}_{2 \mathrm{~A}}$ receptors modulate the cortical $\mathrm{NE}$ release via a mechanism potentially involving interaction between $A_{2 A}$ and $\alpha_{1}$ - and/or $\alpha_{2}$-adrenoceptors, it is possible that CGS 21680 and ZM 241385 modulate the excitability of NE neurons in the LC via an activation and inhibition of $\mathrm{A}_{2 \mathrm{~A}}$ receptors located in the cortex.
In conclusion, those $\mathrm{A}_{2 \mathrm{~A}}$ antagonists potentiate haloperidol-induced DA and NE release in the NAcc and PFC, respectively. This potentiation is mediated, at least in part, via the alteration of firing activity of $\mathrm{NE}$ and DA neurons in the LC and VTA, respectively. The ability of $\mathrm{A}_{2 \mathrm{~A}}$ antagonists to potentiate striatal DA release may diminish some negative side effects of antipsychotic drugs, such as catalepsy. Indeed, several antagonists of $\mathrm{A}_{2 \mathrm{~A}}$ receptors, such as KF1783, KW-6002, SCH 412348, SCH 58261, Lu-AA47070 and JNJ-40255293 reduced haloperidol-induced catalepsy in rats (Kanda et al. 1994; Shiozaki et al. 1999; Varty et al. 2008; Trevitt et al. 2009; Collins et al. 2012; Atack et al. 2014). Since cortical NE play an important role in memory and cognition, the ability of $\mathrm{A}_{2 \mathrm{~A}}$ antagonists to potentiate $\mathrm{NE}$ transmission can improve the clinical efficacy of antipsychotic drugs, and especially in the treatment of negative and cognitive symptoms of schizophrenia (Yamamoto and Hornykiewicz 2004).

Acknowledgements. This study was hosted and funded by Brains On-Line BV and partially supported by the Slovak Academy of Sciences (SAS, via the Scholarship Award to Dr. Eliyahu Dremencov), Scientific Grant Agency of Ministry of Education of Slovak Republic and SAS (grant VEGA-2/0024/15) and Slovak Research and Development Agency (grant APVV-15-0388).

\section{References}

Akhondzadeh S., Shasavand E., Jamilian H., Shabestari O., Kamalipour A. (2000): Dipyridamole in the treatment of schizophrenia: adenosine-dopamine receptor interactions. J. Clin. Pharm. Ther. 25, 131-137 https://doi.org/10.1046/j.1365-2710.2000.00273.x

Allers K. A., Dremencov E., Ceci A., Flik G., Ferger B., Cremers T. I., Ittrich C., Sommer B. (2010): Acute and repeated flibanserin administration in female rats modulates monoamines differentially across brain areas: a microdialysis study. J. Sex Med. 7, 1757-1767 https://doi.org/10.1111/j.1743-6109.2010.01763.x 
Aran S., Proudfit H. K. (1990a): Antinociception produced by interactions between intrathecally administered adenosine agonists and norepinephrine. Brain Res. 513, 255-263

https://doi.org/10.1016/0006-8993(90)90464-M

Aran S., Proudfit H. K. (1990b): Antinociceptive interactions between intrathecally administered alpha noradrenergic agonists and $5^{\text {'}}$-N-ethylcarboxamide adenosine. Brain Res. 519, 287-293 https://doi.org/10.1016/0006-8993(90)90090-X

Atack J. R., Shook B. C., Rassnick S., Jackson P. F., Rhodes K., Drinkenburg W. H., Ahnaou A., Te Riele P., Langlois X., Hrupka B. et al. (2014): JNJ-40255293, a novel adenosine A2A/A1 antagonist with efficacy in preclinical models of Parkinson's disease. ACS Chem. Neurosci. 5, 1005-1019 https://doi.org/10.1021/cn5001606

Bloms-Funke P., Dremencov E., Cremers T. I., Tzschentke T. M. (2011): Tramadol increases extracellular levels of serotonin and noradrenaline as measured by in vivo microdialysis in the ventral hippocampus of freely-moving rats. Neurosci Lett. 490, 191-195 https://doi.org/10.1016/j.neulet.2010.12.049

Carter A. J. (1997): Hippocampal noradrenaline release in awake, freely moving rats is regulated by alpha- 2 adrenoceptors but not by adenosine receptors. J. Pharmacol. Exp. Ther. 281, 648-654

Collins L. E., Sager T. N., Sams A. G., Pennarola A., Port R. G., Shahriari M., Salamone J. D. (2012): The novel adenosine A2A antagonist Lu AA47070 reverses the motor and motivational effects produced by dopamine D2 receptor blockade. Pharmacol. Biochem. Behav. 100, 498-505 https://doi.org/10.1016/j.pbb.2011.10.015

Cremers T. I., Dremencov E., Bosker F. J., Westerink B. H. (2010): Oxazepam and temazepam attenuate paroxetine-induced elevation of serotonin levels in guinea-pig hippocampus. Int. J. Neuropsychopharmacol. 13, 807-811 https://doi.org/10.1017/S146114570999109X

Cunha R. A., Vizi E. S., Ribeiro J. A., Sebastiao A. M. (1996a): Preferential release of ATP and its extracellular catabolism as a source of adenosine upon high- but not low-frequency stimulation of rat hippocampal slices. J. Neurochem. 67, 2180-2187 https://doi.org/10.1046/j.1471-4159.1996.67052180.x

Cunha R. A., Correia-de-Sa P., Sebastiao A. M., Ribeiro J. A. (1996b): Preferential activation of excitatory adenosine receptors at rat hippocampal and neuromuscular synapses by adenosine formed from released adenine nucleotides. Brit. J. Pharmacol. 119, 253-260 https://doi.org/10.1111/j.1476-5381.1996.tb15979.x

Cunha R. A., Johansson B., Constantino M. D., Sebastiao A. M., Fredholm B. B. (1996c): Evidence for high-affinity binding sites for the adenosine A2A receptor agonist [3H] CGS 21680 in the rat hippocampus and cerebral cortex that are different from striatal A2A receptors. Naunyn Schmiedebergs Arch. Pharmacol 353, 261-271 https://doi.org/10.1007/BF00168627

Domenici M. R., Pepponi R., Martire A., Tebano M. T., Potenza R. L., Popoli P. (2004): Permissive role of adenosine A2A receptors on metabotropic glutamate receptor 5 (mGluR5)-mediated effects in the striatum. J. Neurochem. 90, 1276-1279 https://doi.org/10.1111/j.1471-4159.2004.02607.x
Dremencov E., Csatlosova K., Durisova B., Lapinova L., Lacinova L., Jezova D. (2017): Effect of physical exercise and acute escitalopram on the excitability of brain monoamine neurons: in vivo electrophysiological study in rats. Int. J. Neuropsychoph. 20, 585-592 https://doi.org/10.1093/ijnp/pyx024

Dremencov E., El Mansari M., Blier P. (2007a): Distinct electrophysiological effects of paliperidone and risperidone on the firing activity of rat serotonin and norepinephrine neurons. Psychopharmacology (Berl.) 194, 63-72 https://doi.org/10.1007/s00213-007-0818-8

Dremencov E., El Mansari M., Blier P. (2007b): Noradrenergic augmentation of escitalopram response by risperidone: electrophysiologic studies in the rat brain. Biol. Psychiatry 61, 671-678 https://doi.org/10.1016/j.biopsych.2006.05.015

Dremencov E., El Mansari M., Blier P. (2009): Effects of sustained serotonin reuptake inhibition on the firing of dopamine neurons in the rat ventral tegmental area. J. Psychiatry Neurosci. 34, 223-229

Dremencov E., Folgering J. H. A., Hogg S., Tecott L., Cremers T. I. F. H. (2011): The role of $5-\mathrm{HT}(2 \mathrm{C})$ receptors in the pathophysiology and treatment of depression. In: 5-HT2C Receptors in the Pathophysiology of CNS Disease. (Eds. G. Di Giovanni, E. Esposito, V. Di Matteo), pp. 249-260, Humana Press, London

Dremencov E., Gispan-Herman I., Rosenstein M., Mendelman A., Overstreet D. H., Zohar J., Yadid G. (2004a): The serotonindopamine interaction is critical for fast-onset action of antidepressant treatment: in vivo studies in an animal model of depression. Prog. Neuropsychopharmacol. Biol. Psychiatry 28, 141-147

https://doi.org/10.1016/j.pnpbp.2003.09.030

Dremencov E., Nahshoni E., Levy D., Mintz M., Overstreet D. H., Weizman A., Yadid G. (2004b): Dimensional complexity of the neuronal activity in a rat model of depression. Neuroreport 15, 1983-1986 https://doi.org/10.1097/00001756-200408260-00030

Dremencov E., Newman M. E., Kinor N., Blatman-Jan G., Schindler C. J., Overstreet D. H., Yadid G. (2005): Hyperfunctionality of serotonin-2C receptor-mediated inhibition of accumbal dopamine release in an animal model of depression is reversed by antidepressant treatment. Neuropharmacology 48, 34-42

https://doi.org/10.1016/j.neuropharm.2004.09.013

Dremencov E., Weizmann Y., Kinor N., Gispan-Herman I., Yadid G. (2006): Modulation of dopamine transmission by 5 HT2C and $5 \mathrm{HT} 3$ receptors: a role in the antidepressant response. Curr. Drug Targets 7, 165-175 https://doi.org/10.2174/138945006775515491

Ferre S., Herrera-Marschitz M., Grabowska-Anden M., Casas M., Ungerstedt U., Anden N. E. (1991a): Postsynaptic dopamine/ adenosine interaction: II. Postsynaptic dopamine agonism and adenosine antagonism of methylxanthines in short-term reserpinized mice. Eur. J. Pharmacol. 192, 31-37 https://doi.org/10.1016/0014-2999(91)90065-X

Ferre S., Herrera-Marschitz M., Grabowska-Anden M., Ungerstedt U., Casas M., Anden N. E. (1991b): Postsynaptic dopamine/ adenosine interaction: I. Adenosine analogues inhibit dopa- 
mine D2-mediated behaviour in short-term reserpinized mice. Eur. J. Pharmacol. 192, 25-30

https://doi.org/10.1016/0014-2999(91)90064-W

Flik G., Dremencov E., Cremers T. I., Folgering J. H., Westerink B. H. (2011): The role of cortical and hypothalamic histamine-3 receptors in the modulation of central histamine neurotransmission: an in vivo electrophysiology and microdialysis study. Eur. J. Neurosci. 34, 1747-1755 https://doi.org/10.1111/j.1460-9568.2011.07893.x

Flik G., Folgering J. H., Cremers T. I., Westerink B. H., Dremencov E. (2015): Interaction between brain histamine and serotonin, norepinephrine, and dopamine systems: in vivo microdialysis and electrophysiology study. J. Mol. Neurosci. 56, 320-328 https://doi.org/10.1007/s12031-015-0536-3

Fuxe K., Borroto-Escuela D., Fisone G., Agnati L. F., Tanganelli S. (2014): Understanding the role of heteroreceptor complexes in the central nervous system. Curr. Protein Pept. Sci. 15, 647 https://doi.org/10.2174/138920371507140916122738

Golembiowska K., Dziubina A. (2004): Striatal adenosine A(2A) receptor blockade increases extracellular dopamine release following l-DOPA administration in intact and dopaminedenervated rats. Neuropharmacology 47, 414-426 https://doi.org/10.1016/j.neuropharm.2004.04.018

Golembiowska K., Dziubina A. (2012a): Effect of adenosine A(2A) receptor antagonists and L-DOPA on hydroxyl radical, glutamate and dopamine in the striatum of 6-OHDA-treated rats. Neurotox. Res. 21, 222-230 https://doi.org/10.1007/s12640-011-9263-x

Golembiowska K., Dziubina A. (2012b): The effect of adenosine $\mathrm{A}(2 \mathrm{~A})$ receptor antagonists on hydroxyl radical, dopamine, and glutamate in the striatum of rats with altered function of VMAT2. Neurotox. Res. 22, 150-157 https://doi.org/10.1007/s12640-012-9316-9

Harper L. K., Beckett S. R., Marsden C. A., McCreary A. C., Alexander S. P. (2006): Effects of the A 2A adenosine receptor antagonist KW6002 in the nucleus accumbens in vitro and in vivo. Pharmacol. Biochem. Behav. 83, 114-121 https://doi.org/10.1016/j.pbb.2005.12.014

Kanda T., Shiozaki S., Shimada J., Suzuki F., Nakamura J. (1994): KF17837: a novel selective adenosine A2A receptor antagonist with anticataleptic activity. Eur. J. Pharmacol. 256, 263-268 https://doi.org/10.1016/0014-2999(94)90551-7

Krügel U. (2016): Purinergic receptors in psychiatric disorders. Neuropharmacology 104, 212-225 https://doi.org/10.1016/j.neuropharm.2015.10.032

Madularu D., Shams W. M., Brake W. G. (2014): Estrogen potentiates the behavioral and nucleus accumbens dopamine response to continuous haloperidol treatment in female rats. Eur. J. Neurosci. 39, 257-265 https://doi.org/10.1111/ejn.12401

Moscoso-Castro M., Gracia-Rubio I., Ciruela F., Valverde O. (2016): Genetic blockade of adenosine A2A receptors induces cognitive impairments and anatomical changes related to psychotic symptoms in mice. Eur. Neuropsychopharmacol. 26, 1227-1240 https://doi.org/10.1016/j.euroneuro.2016.04.003

Paxinos G., Watson C. (2013): The Rat Brain in Stereotaxic Coordinates. Academic Press, Cambridge
Prus A. J., Huang M., Li Z., Dai J., Meltzer H. Y. (2007): The neurotensin analog NT69L enhances medial prefrontal cortical dopamine and acetylcholine efflux: potentiation of risperidone-, but not haloperidol-, induced dopamine efflux. Brain Res. 1184, 354-364 https://doi.org/10.1016/j.brainres.2007.09.092

Rebola N., Sebastiao A. M., de Mendonca A., Oliveira C. R., Ribeiro J. A., Cunha R. A. (2003): Enhanced adenosine A2A receptor facilitation of synaptic transmission in the hippocampus of aged rats. J. Neurophysiol. 90, 1295-1303 https://doi.org/10.1152/jn.00896.2002

Richelson E., Nelson A. (1984): Antagonism by neuroleptics of neurotransmitter receptors of normal human brain in vitro. Eur. J. Pharmacol. 103, 197-204 https://doi.org/10.1016/0014-2999(84)90478-3

Richelson E., Souder T. (2000): Binding of antipsychotic drugs to human brain receptors focus on newer generation compounds. Life Sci. 68, 29-39 https://doi.org/10.1016/S0024-3205(00)00911-5

Sebastiao A. M., Ribeiro J. A. (1996): Adenosine A2 receptormediated excitatory actions on the nervous system. Prog. Neurobiol. 48, 167-189 https://doi.org/10.1016/0301-0082(95)00035-6

Shiozaki S., Ichikawa S., Nakamura J., Kitamura S., Yamada K., Kuwana Y. (1999): Actions of adenosine A2A receptor antagonist KW-6002 on drug-induced catalepsy and hypokinesia caused by reserpine or MPTP. Psychopharmacology 147, 90-95 https://doi.org/10.1007/s002130051146

Shirokawa T., Ishida Y., Isobe K. (2003): Age-related changes in the release and uptake activity of presynaptic axon terminals of rat locus coeruleus neurons. Neurosci Lett. 344, 212-214 https://doi.org/10.1016/S0304-3940(03)00463-4

Stone E. A., Quartermain D., Lin Y., Lehmann M. L. (2007): Central alpha1-adrenergic system in behavioral activity and depression. Biochem. Pharmacol. 73, 1063-1075 https://doi.org/10.1016/j.bcp.2006.10.001

Takeda K., Ueda T. (2017): Effective mechanism for synthesis of neurotransmitter glutamate and its loading into synaptic vesicles. Neurochem. Res. 42, 64-76 https://doi.org/10.1007/s11064-016-2037-3

Tanda G., Valentini V., De Luca M. A., Perra V., Serra G. P., Di Chiara G. (2015): A systematic microdialysis study of dopamine transmission in the accumbens shell/core and prefrontal cortex after acute antipsychotics. Psychopharmacology 232, $1427-1440$ https://doi.org/10.1007/s00213-014-3780-2

Tozzi A., de Iure A., Di Filippo M., Tantucci M., Costa C., Borsini F., Ghiglieri V., Giampa C., Fusco F. R., Picconi B., Calabresi P. (2011): The distinct role of medium spiny neurons and cholinergic interneurons in the $\mathrm{D}(2) / \mathrm{A}(2) \mathrm{A}$ receptor interaction in the striatum: implications for Parkinson's disease. J. Neurosci. 31, 1850-1862 https://doi.org/10.1523/JNEUROSCI.4082-10.2011

Trevitt J., Vallance C., Harris A., Goode T. (2009): Adenosine antagonists reverse the cataleptic effects of haloperidol: implications for the treatment of Parkinsons disease. Pharmacol. Biochem. Behav. 92, 521-527 https://doi.org/10.1016/j.pbb.2009.02.001 
Varty G. B., Hodgson R. A., Pond A. J., Grzelak M. E., Parker E. M., Hunter J. C. (2008): The effects of adenosine A2A receptor antagonists on haloperidol-induced movement disorders in primates. Psychopharmacology 200, 393-401 https://doi.org/10.1007/s00213-008-1214-8

Visser A. K., Kleijn J., van Faassen M. H., Dremencov E., Flik G., Kema I. P., Den Boer J. A., van Waarde A., Dierckx R. A., Bosker F. J. (2015): Serotonin-2C antagonism augments the effect of citalopram on serotonin and dopamine levels in the ventral tegmental area and nucleus accumbens. Neurochem. Int. 81, 10-15 https://doi.org/10.1016/j.neuint.2014.12.006

Westerink B. H. C., Cremers T. I. F. H. (2007): Handbook of microdialysis: Methods, Applications and Perspectives. Academic Press, Cambridge

Yamada M., Kawahara Y., Kaneko F., Kishikawa Y., Sotogaku N., Poppinga W. J., Folgering J. H., Dremencov E., Kawahara H., Nishi A. (2013): Upregulation of the dorsal raphe nucleus-prefrontal cortex serotonin system by chronic treatment with escitalopram in hyposerotonergic Wistar-Kyoto rats. Neuropharmacology $72,169-178$

https://doi.org/10.1016/j.neuropharm.2013.04.044

Yamamoto K., Hornykiewicz O. (2004): Proposal for a noradrenaline hypothesis of schizophrenia. Prog. Neuropsychopharmacol. Biol. Psychiatry. 28, 913-922

https://doi.org/10.1016/j.pnpbp.2004.05.033

Zhang W., Perry K. W., Wong D. T., Potts B. D., Bao J., Tollefson G. D., Bymaster F. P. (2000): Synergistic effects of olanzapine and other antipsychotic agents in combination with fluoxetine on norepinephrine and dopamine release in rat prefrontal cortex. Neuropsychopharmacology 23, 250-262

https://doi.org/10.1016/S0893-133X(00)00119-6

Received: July 14, 2017

Final version accepted: August 24, 2017

First published online: August 31, 2017 